\title{
Factors Affecting Community Behavior towards Dengue Fever Occurrence in the Minapolitan Area of Tulungaggung Regency
}

\author{
Titis Sfabrila Karira ${ }^{1}$, Lilik Zuhriyah ${ }^{2}$, Rita Parmawati ${ }^{3}$ \\ \{tskarira@gmail.com¹, lilik.zuhriyah@gmail.com², rita_parmawati@ub.ac.id ${ }^{3}$ \} \\ Universitas Brawijaya, Indonesia ${ }^{1,2,3}$
}

\begin{abstract}
Minapolitan is a fisheries-based regional development strategy, but the pond wastewater in there has odors containing several compounds that can stimulate the olfactory nerve of mosquito, mainly Aedes spp. It becomes the cause of Dengue Hemorrhagic Fever (DHF) and caused 128 cases and four deaths in Tulungagung Regency. The aim of this research is to analyze the factors that influence people's behavior towards the incidence of Dengue Hemorrhagic Fever (DHF) in the Minapolitan Area of Tulungaggung Regency. An interview was conducted with a key person and distributed the questionnaire in 98 respondents. Then, data were analyzed with multiple linear regression to examined the variable that have affect the DHF suspect. DHF suspect is affected by the level of economy and socio-cultural conditions. It has a negative effect on DHF suspects, because if the level of economy and socio-cultural conditions is increasing, then DHF suspect will decrease. As for health behavior, if there is an increase, DHF suspect will increase. However, it is because the community still underestimates the steps in preventing dengue fever. Steps that can take are $3 \mathrm{M}$ (Closing, Draining, and Burying) so that there is no medium for mosquitoes, mainly Aedes aegypti, to breed.
\end{abstract}

Keywords: Behavioral Factor, DHF, Minapolitan.

\section{Introduction}

Regional development is expected to be carried out in a balanced and un-centralized way, in addition community participation is needed and it is important to strengthening local potential that can support and succeed the development of an area [1]. One of the government's steps in developing rural areas is the Agropolitan and Minapolitan strategies [2]. Minapolitan is a regional development strategy based on the development of fisheries potential that integrated with several other sectors, including the production, trade, and services sectors. Development of Agropolitan and Minapolitan Areas in East Java has started since 2003, following the East Java Province Long Term Program Plan 2005-2025.

Minapolitan areas in East Java Province, one of which located in Gondang District Gondosuli Village following Tulungagung District Regulation Number 10 of 2008 concerning the Long-Term Development Plan of Tulungagung Regency in 2005-2025. This location is selected because it has abundant potential of inland fisheries, with an area of cultivation reaching 16 hectares, with 391 people cultivating. Freshwater fish in here are Gurami, Catfish, Nila, Ornamental Fish, and Patin. The average ornamental fish production reaches 11,010 fish/year 
and for aquaculture fish reaches 1,145 tons/year [3]. Thus, Tulungagung Regency is currently one of production center of in East Java Province [4].

The development of an area into the Minapolitan and Agropilitan Regions has positive and negative impacts. The negative impact of the Minapolitan Area in Gondosuli Village, Gondang District, has caused several new problems [5]. Environmental pollution has become one of the negative adverse impacts on the community and has become one of the breeding grounds of vectors. A type of vector that has a moderate reproduction rate is a mosquito. One example is the Aedes spp. Which can transmit dengue hemorrhagic fever, which is currently quite unsettling to the public, and in the world, nearly 390 million people have infected each year [6]. Waste from fish ponds contains carbon dioxide (CO2) compounds, and ammonia gas is very easily recognized and very quickly stimulates the olfactory nerve of mosquito [7].

DHF cases per province in Indonesia in 2017 stated that East Java was in the second position with the highest number of 7,838 cases [6]. In 2017 the incidence of Dengue Hemorrhagic Fever (DHF) in Tulunggagung reached 128 cases and four deaths and increased rapidly from January to July 2019, which had an incidence of 863 cases [8]. Many factors play an essential role in the spread of disease, mainly the home environment that does not meet the requirements [9]. Besides, the behavior of the host (human) is also quite influential on this matter. These factors can be influenced by several indicators, including age, level of education, and geographical conditions of the region. Increasing the incidence of DHF in Tulungagung Regency is one of the bases in conducting research aimed at analyzing the factors that influence people's behavior towards DHF events in the Minapolitan area of Tulungaggung Regency.

\section{Research Methods}

\subsection{Study Area}

This research was carried out in Gondosuli Village, Gondang District, which was in the south of Tulungagung Regency. This area includes the Minapolitan Area, with an area of 37.65 $\mathrm{km}^{2}$. The fishery products from the Minapolitan Region were ornamental fish, aquaculture (Gurami, Catfish, Nila, Ornamental Fish, and Patin), and processed fish (Pangan and shredded). The map of the research location can be seen in Figure 1.

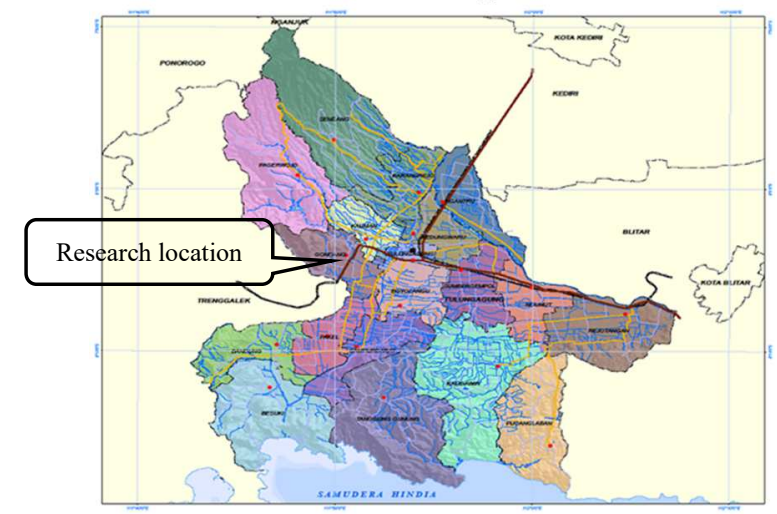

2.2 Data Collection

Fig. 1. Minapolitan Area in Tulungagung Regency. 
This research used an observational analytical method. The research design used was casecontrol. The sampling technique in this research was taken using the Slovin formula $(\alpha=10 \%)$. So, the sample of this research was 96 respondents. The data needed was primary and secondary data. Primary data in this study were obtained by interview using questionnaire instruments and observation sheets. The dependent variable in this study is the incidence of suspect DHF, and the independent variable is the level of an economy, social culture, and health behavior. Secondary data in this study were obtained from literature, the internet, and other agencies related to research such as the Tulungagung Health Office, the Tulungagung District Environment Office, and the Gondosuli Village Parent Book.

\subsection{Data Analysis}

Analysis of the data used in this study is multiple linear regression with the enter method. This linear regression analysis method is one type of parametric statistical analysis that requires the data to be analyzed must meet the assumptions, among others, meet the conditions of existence assumptions, independence assumptions, linearity assumptions, normality assumptions, multicollinearity assumptions, and homosedacity assumptions [10].

\section{Result and Discussion}

The dependent variable of this study was suspect DHF, and the independent variables in this study were the level of the economy, socio-cultural conditions, and health behavior. Based on the results of data normality analysis using Kolmogorov Smirnov, it shows that the data are normally distributed (Table 1).

Table 1. Kolmogorov-Smirnov Normality Test

\begin{tabular}{|c|c|c|c|c|c|}
\hline \multicolumn{6}{|c|}{ One-Sample Kolmogorov-Smirnov Test } \\
\hline & & $\begin{array}{l}\text { Economic } \\
\text { Level }\end{array}$ & $\begin{array}{l}\text { Socio-cultural } \\
\text { Conditions }\end{array}$ & $\begin{array}{c}\text { Community } \\
\text { Behavior }\end{array}$ & Suspect DHF \\
\hline $\mathrm{N}$ & & 96 & 96 & 96 & 100 \\
\hline \multirow{2}{*}{$\begin{array}{l}\text { Normal } \\
\text { Parameters }^{\mathrm{a}}\end{array}$} & Mean & 7.1979 & 11.0729 & 37.9167 & 12.8300 \\
\hline & Std. Deviation & 3.01093 & 1.13550 & 1.86754 & 1.13756 \\
\hline \multirow{3}{*}{$\begin{array}{l}\text { Most Extreme } \\
\text { Differences }\end{array}$} & Absolute & .287 & .245 & .177 & .339 \\
\hline & Positive & .287 & .213 & .132 & .251 \\
\hline & Negative & -.161 & -.245 & -.177 & -.339 \\
\hline \multicolumn{2}{|c|}{ Kolmogorov-Smirnov Z } & 2.808 & 2.403 & 1.738 & 3.394 \\
\hline \multicolumn{2}{|c|}{ Asymp. Sig. (2-tailed) } & .000 & .000 & .005 & .000 \\
\hline
\end{tabular}

The results from Kolmogorov-Smirnov One-Sample Test show that the data distribution is normal. The data can be categorized as normally distributed if the level of significance has a value of more than 0.05 . From Table 1, all variables (economic level, socio-cultural conditions, 
community behavior, and suspect DHF) have a value of $\alpha<0.05$. So, it can be interpreted that the data is normally distributed and can be conducted a further test.

Based on multiple linear regression tests that had conducted, the determination analysis table (table 2) shows that the value of $\mathrm{R}^{2}$ (R squared) is 0.092 or $9.2 \%$. It shows that the percentage of each independent variable has an effect of $9.2 \%$ on the dependent variable. So, it is known that the economic level, socio-cultural conditions, and health behavior variables can explain $9.2 \%$ of the variation of the dependent variable, while the remaining $90.8 \%$ is influenced or explained by other variables not included in this research.

The partial t-test is shown in Table 3. Based on the table, it is known that significance value of the variable level of economy is 0.036 ; the value of significance for social-cultural conditions is 0.280 , and the significance value on health behavior is 0.478 . An independent variable considers influencing the dependent variable if the significance value is more than 0.05 ( $\alpha$ $<0.05)$. Therefore, economic level variables have a significant influence on suspect DHF in the Minapolitan Region of Tulungagung Regency. The value of beta $(\beta)$ indicates the magnitude of the role of the independent variable on the dependent variable (suspect DHF). In table 3, the highest Beta value own by the Health Behavior Variable that is 0.044 , while the other variables are negative.

Table 2. Regression Analysis

\begin{tabular}{|c|c|c|c|c|c|c|c|c|c|}
\hline \multicolumn{10}{|c|}{ Model Summary } \\
\hline \multirow[b]{2}{*}{ Model } & \multirow[b]{2}{*}{$\mathrm{R}$} & \multirow{2}{*}{$\begin{array}{c}\mathrm{R} \\
\text { Square }\end{array}$} & \multirow{2}{*}{$\begin{array}{l}\text { Adjusted } \\
\text { R Square }\end{array}$} & \multirow{2}{*}{$\begin{array}{l}\text { Std. Error of } \\
\text { the Estimate }\end{array}$} & \multicolumn{5}{|c|}{ Change Statistics } \\
\hline & & & & & $\begin{array}{l}\text { R Square } \\
\text { Change }\end{array}$ & $\begin{array}{c}\mathrm{F} \\
\text { Change }\end{array}$ & df1 & $\mathrm{df} 2$ & $\begin{array}{c}\text { Sig. F } \\
\text { Change }\end{array}$ \\
\hline 1 & $.304^{\mathrm{a}}$ & .092 & .063 & 1.11774 & .092 & 3.118 & 3 & 92 & .030 \\
\hline
\end{tabular}

Table 3. T-test Analysis

\begin{tabular}{|c|c|c|c|c|c|c|}
\hline \multicolumn{7}{|c|}{ Coefficients $^{\mathrm{a}}$} \\
\hline & \multirow[t]{2}{*}{ Model } & \multicolumn{2}{|c|}{$\begin{array}{l}\text { Unstandardized } \\
\text { Coefficients }\end{array}$} & \multirow{2}{*}{$\begin{array}{c}\text { Standardized } \\
\text { Coefficients }\end{array}$} & \multirow[t]{2}{*}{$\mathrm{t}$} & \multirow[t]{2}{*}{ Sig. } \\
\hline & & B & Std. Error & & & \\
\hline \multirow[t]{4}{*}{1} & (Constant) & 13.104 & 2.723 & & 4.812 & .000 \\
\hline & economic level & -.089 & .042 & -.232 & -2.130 & .036 \\
\hline & economic level & -.120 & .111 & -.118 & -1.087 & .280 \\
\hline & economic level & .044 & .062 & .072 & .712 & .478 \\
\hline a. De & endent Variable: S & ct DBD & & & & \\
\hline
\end{tabular}

It concludes that for every $1 \%$ increase in the proportion of economic level variable, then the value of the suspect will DHF decreases by 0.089 after being controlled by socio-cultural conditions and health behavior variables. If there is a $1 \%$ increase in the proportion of sociocultural conditions variables, the value of the suspect DHF decreases by 0.120 after being controlled by health behavior and economic level variables. Meanwhile, if there is a $1 \%$ increase in the proportion of health behavior variables, the value of the suspect DHF increases by 0.44 , after being controlled by socio-cultural conditions and economic level variables. Then from the 
results of multiple regression analysis can be known as the final linear equation model of suspect DHF is as follows:

$$
\text { Suspect DHF=13,104-0,089X1-0,120X2+0,44X3 }
$$

The independent variable influencing people's behavior towards suspect DHF in the Minapolitan Region of Tulungaggung Regency is the economic level of the community. However, the correlation between suspect DHF (Y) with economic level and socio-cultural conditions variables showed s negative results, so if the level of the economy and social culture of the community is getting better or increasing, then suspect DHF in society will decrease. It is because the level of the economy has a relationship with the level of public health. The relationship between economic level and public health is still unclear. However, health and economic performance are interlinked. Wealthier countries can be said that have a healthier population. It is a fundamental truth that poverty, mainly through infant malnourishment and mortality, adversely affects life expectancy. National income has a direct effect on the development of health systems, through insurance coverage and public spending, for instance. As demonstrated in 1997 by the WHO Commission on Macroeconomics and Health for a panel of 167 countries, while health expenditures are determined mainly by national income, they increase faster than income [11].

Stable socio-cultural conditions can also reduce suspect DHF because, in this variable, there are components of community activities, including Gotong Royong. The high level of Gotong Royong, the desire to help one another, and better community-to-people education will make individuals who remind one another to maintain hygiene and sanitation. In line with the results of [12] the relationship between social capital and the participation in eradicating mosquito nests in households, as well as the level of participation among residents regarding waste management, shows a strong relationship to minimize the occurrence of vector breeding (mosquitoes). Also, social and cultural variables will increase the diffusion of information about behaviors that improve health and promote a healthy lifestyle.

Meanwhile, the health behavior variable has a positive value, which indicates that if the level of public health behavior is quite good, so it can increase DHF suspects in the community. It is because the community already has good health behaviors, but there are still many people who underestimate the incidence of DHF. So, they are underestimating the $3 \mathrm{M}$ program for the prevention of DHF. To prevent the spread of DHF can be carried out by vector control of Aedes aegypti mosquitoes through eradication of larvae by several physically appropriate methods $(3 \mathrm{M}=$ Closing, Draining, and Burying) and chemical methods by giving abate powder in a month, and fogging. Majority of people still do not use abate to kill mosquito larvae in their bathing pools and still often accumulate water in reservoirs, so that although other health behaviors are classified as good enough, essential behaviors in preventing DHF are still very rarely performed by the community.

\section{Conclusion}

The factors that influence people's behavior towards suspect DHF in the Minapolitan area of Tulungaggung Regency are the level of the economy, social culture, and health behavior. When the economic level and socio-cultural of the community are in better condition, it will further reduce the level of DHF suspects. When the health behavior is better, it will increase the 
DHF suspects, this is due to the majority of people in the Minapolitan Region are still underestimating several steps in preventing DHF which include 3M (Closing, Draining, and Burying) a household tool that can be used as a medium for the development of mosquitoes, primarily Aedes aegypti.

\section{References}

[1] B. Susantono, Manajemen infrastruktur dan pengembangan wilayah. Penerbit Universitas Indonesia, 2012.

[2] Kementerian Pekerjaan Umum, "Agropolitan dan Minapolitan Konsep Kawasan Menuju Keharmonian.” Jakarta, 2012.

[3] Badan Pusat Statistik (BPS) Kabupaten Tulungagung, Kecamatan Gondang dalam Angka. Tulungagung: BPS, 2019.

[4] Direktur Jendral Perikanan Budidaya, Laporan Kinerja (LKJ). Jakarta: Kementrian Kelautan Dan Perikanan, 2016.

[5] H. D. P. Kurniawan, "Evaluasi Dampak Program Pengembangan Kawasan Minapolitan Berbasis Perikanan Budidaya bagi Masyarakat Desa Gondosuli Kecamatan Gondang Kapupaten Tulungagung." Universitas Airlangga, 2018.

[6] Kemenkes RI, "Demam Berdarah," Pusat Data dan Informasi Kementerian Kesehatan RI, 2019. [Online]. Available: www.depkes.go.id. [Accessed: 12-Nov-2019].

[7] S. Sayono, "Pengaruh Modifikasi Ovitrap terhadap Jumlah Nyamuk Aedes yang Terperangkap." Program Pasca Sarjana Universitas Diponegoro, 2008.

[8] Dinas Kesehatan Tulungagung, Laporan Kejahian Demam Berdarah. Tulungagung, 2019.

[9] S. Notoatmodjo, H. Anwar, N. H. Ella, and K. Tri, "Promosi kesehatan di sekolah," Jakarta: rineka cipta, pp. 21-23, 2012.

[10] O. Nainggolan, "Hubungan Indikator Perilaku dan Pelayanan Kesehatan dengan Sub Indeks Penyakit Tidak Menular (Analisis Lanjut IPKM 2014)," Media Penelit. dan Pengemb. Kesehat., vol. 28 , no. 3, pp. 137-146, 2018.

[11] OECD, "Health and Economic: A Vital Relationship," OECD Observer, 2019. [Online]. Available:

https://oecdobserver.org/news/archivestory.php/aid/1241/Health_and_the_economy:_A_vital_re lationship_.html. [Accessed: 11-Nov-2019].

[12] H. S. Kasjono, "Hubungan Modal Sosial dengan Partisipasi Pemberantasan Sarang Nyamuk Demam Berdarah Dengue di Kabupaten Bantul," 2017. 